\title{
Are "dirty" industries looking for pollution havens? - an overview of selected studies
}

Anetta Kuna-Marszałek*

\section{Introduction}

In the subject-matter literature, we can read that industries move across countries in the pursuit of the least stringent environmental regulations. Such migration emerges as an effect of, inter alia, trade liberalisation and capital flows, and it deepens differences in the environmental performance of "rich" and "poor" countries. The pollution haven hypothesis assumes that enterprises (especially high-emission ones) strive to locate their operations in countries (usually little-developed ones) or areas of low environmental standards to avoid high costs of production. ${ }^{1}$ This is particularly true of industries such as machinery, electronics, chemicals, food processing, non-ferrous metals, mineral products, the manufacturing of plastics, rubber, or transport services (Chodyński 2011, p. 114). It is hard to contradict such a statement since these industries exploit the environment the most and actively contribute to its advancing degradation. The processes are intensified by production organisation where ownership control over individual links of a product value chain is replaced with a system of orders (Pietrewicz 2011, p. 82).

It is widely believed that, guided by the "as cheap as possible" principle, international enterprises can quickly change suppliers often by "exploiting the environment" in subsequent regions. Moving onerous production to countries with less stringent environmental standards and regulations means that pollutant emissions are also transferred internationally, which hinders solving global environmental problems. "Dirty" investment projects may mean shifting environmental risks to weaker partners.

\footnotetext{
* Anetta Kuna-Marszałek - PhD, University of Lodz, Faculty of Economics and Sociology, Institute of Economics, Department of International Trade, anetta.marszalek@uni.lodz.pl.

${ }^{1}$ In the literature, the phenomenon is referred to as the "dirty industry migration", "industry flight", or "displacement of industry".
} 
The issue of dirty industry migration has been the centre of economists' attention for quite some time; thus, answering the question of whether dirty industries are looking for pollution havens seems to be interesting. However, in the literature, there is no consensus as to whether enterprises migrate in the pursuit of more relaxed environmental standards. While theoretical works tend to confirm this hypothesis, conclusions from empirical models are not unambiguous. Hence, the aim of the paper is to provide an overview of the theoretical and empirical studies that focus on the migration of dirty industries to pollution havens. The review of the research allows us to show the different approaches of researchers to the analysed issue, points out the inconsistency of their conclusions and identifies the existing research gaps. Below, we can find in-depth literature reviews devoted to the subject in question.

\section{Reasons behind dirty industry migration}

It is quite easy to explain why enterprises benefit from the freedom to establish themselves in an open market and migrate, seeking to locate their operations in less stringent environmental regimes (Xing, Kolstad 2002). First, complying with stringent environmental regulations may increase the cost of production as it requires using technologically advanced equipment and additional solutions, e.g., installing purifying or filtering devices. Second, stringent environmental regulations may restrict the disposal of industrial waste, sometimes even banning the use of certain production factors (toxic to the environment) or the generation of specific types of pollution. As a result, the costs of producing goods and services may be higher. Thus, it is in an enterprise's interest to locate manufacturing processes in a region where production costs are lower (assuming a company can do it with other determinants remaining unchanged).

Lower standard requirements for manufacturing methods and processes diversify costs of running a business between countries and thus determine business location decisions. This is the effect of the cost minimisation principle. Production relocation to countries where the environmental regime is less stringent is a typical example of eco-dumping, environmental neo-colonialism, or even eco-imperialism (Czaja 2004, p. 11). It leads to serious environmental damage, the depletion of natural resources, increased risk of illness and higher mortality rates, and the overall worsening of the living conditions of local communities. That, in turn, arouses controversies and stirs heated debates amongst environmentalists or economists.

On the other hand, however, the distribution of industries that are motivated by the differences in the stringency of environmental regulations is optimal and helps countries to exploit or create comparative advantages. Additionally, less 
stringent environmental requirements may be the effects of exporters' lobbying or incentives designed to attract foreign investors. Poorly developed countries insist on hosting industrial investment projects even in industries phased out by other countries due to environmental concerns.

\section{Studies that reject the pollution haven hypothesis}

The subject-matter literature includes works which challenge the role of environmental fees in making an internationalisation decision irrespective of whether the costs of environmental compliance are borne in the home country or abroad. In both cases, an enterprise may decide to more intensely use production factors whose deployment is less harmful to the environment (e.g. capital) and this way reduce environmental charges (Eskeland, Harrison 2002, p. 27).

Doubts as to whether an expansion overseas is motivated by higher costs of emissions reduction in the home country can be found, e.g., in the work by Walter (1973). He states that the United States' environmental policy turned out to be "neutral" for decisions made by industries to migrate abroad.

The absence of evidence confirming the existence of pollution havens can also be noticed in the publication by Bartik (1988). The author argues that production location decisions depend on, inter alia, differences in tax rates between regions, the availability of state aid, and the unionisation of labour, while differences in environmental regulations are viewed as of little importance to enterprises. We can find similar conclusions in many other works that discuss the examples from the American market (Friedman, Gerlowski, Silberman 1992; Levinson 1996; Goodstein 1994).

There is also an interesting aspect of the real competitive advantage held by developing countries in the export of goods whose production causes significant environmental damage. One might expect that enterprises that do not pay environmental charges offer cheaper products that are more attractive to price-sensitive customers. The issue was taken up by Low and Yeats (1992), who estimated a "Revealed Comparative Advantage" (RCA) index. Whenever an RCA assumes values higher than 1 , the revealed comparative advantage that results from, e.g., lower environmental charges (or the absence thereof), is confirmed for a given industry. Their analysis was carried out for heavily polluting industries, and the data originated from 109 countries across the globe. Their findings showed that the RCA index was higher for developing countries than for industrialised ones. That was particularly true of Eastern Europe, Latin America, and Western Asia. In addition, Low and Yeats $(1992$, pp. 98, 102) observed that: 
- the number of developing countries that hold a comparative advantage in dirty industries is continuously growing (it more than tripled over the years covered by the study),

- dirty industries get an increasingly bigger share in exports from developing countries,

- the share of dirty industries in total exports from highly developed countries is decreasing,

- the share of dirty industries exports in global trade is decreasing.

Thus, we may assume that the most polluting industries have become geographically dispersed, and most of them can be found in developing countries. By formulating such conclusions, Low and Yeats confirm the hypothesis about the migration of dirty industries, but they do not draw a link between it and more stringent environmental regulations in developed countries. They attribute the phenomenon to lower labour costs (metalworking industry), the availability of natural resources (e.g., wood and paper industry, non-ferrous metals, or oil refineries), or differences in income and development levels.

On the other hand, by examining the concentration of pollutants in selected regions considered pollution havens, Wheeler (2001) rejected the hypothesis about the migration of dirty industries. He demonstrated that in countries which in the 1990s attracted a considerable proportion of global FDI, such as Brazil, Mexico or China, ${ }^{2}$ there were decreases in cities of total suspended particles, the side-effect of industrial operations. The results of his research also clearly contradicted the "race to the bottom" hypothesis. ${ }^{3}$ In most urban areas in China, Brazil, and Mexico covered by the analysis, the quality of air significantly improved.

Since pollution havens attract dirty production, one might expect that the presence of international enterprises operating within their territories would be more detrimental to the environment than that of domestic businesses. However, according to many authors, e.g., Eskeland and Harrison (2002), Wang and Jin (2002), Liang (2008), or Jiang, Lin, and Lin (2014), it is quite the opposite. Eskeland and Harrison (2002) investigated the operations of foreign investors in industries, which are heavy air polluters. Foreign companies implement energy-saving technologies and use more environmentally friendly energy sources much more frequently than domestic ones. The authors based their conclusions on investment

\footnotetext{
${ }^{2}$ In the 1990s, the inflow of FDI into these three countries was the highest in the group of developing countries. For China, it reached an annual average of $28 \%$, while for Mexico and Brazil, it was $9 \%$ and $7 \%$, respectively. The value of cumulated FDI for these 3 countries represented $60 \%$ of the total for all the developing countries.

3 Tax, wage, social, or environmental dumping aimed to lower standards observed in a given country to make it "cheaper" than other countries.
} 
directions observed in four developing countries: Morocco, the Ivory Coast, Mexico, and Venezuela. Most investments in the first two countries originated from France, while in the latter two, from the United States.

Similar conclusions can be found in works by Wang and Jin (2002), Liang (2008), or Jiang, Lin and Lin (2014), who analysed the burden posed by operations of international and local enterprises in China. Jiang, Lin and Lin estimated that emissions of harmful chemical compounds, such as $\mathrm{SO}_{2}$ or soot, from economic operations pursued by foreign investors were much smaller than from the same operations of Chinese companies. The same was observed for sewage discharged in coastal cities. This, again, could be attributed to the more efficient use of energy and the deployment of more modern technologies by foreign companies.

In the literature, the theme of foreign investors contributing to the improvement of the status of the environment in a host country is referred to as the "pollution halo effect hypothesis". ${ }^{4}$ Amongst works that discuss this aspect, it is worth mentioning Birdsall and Wheeler (1993), Zarsky (1999), Gallagher and Zarsky (2007), and Asghari (2013). Investors, mainly from highly developed countries, who use more advanced and cleaner technologies contribute to the transfer of knowledge and modern management practices, which may improve the overall operational effectiveness and performance of local businesses that cooperate with them. One such effect may be better environmental protection in the host country. In addition, foreign investors may prefer investing in regions where environmental standards are very stringent, as evidenced by Dean, Lovely and Wang (2009) or Kirkpatrick and Shimamoto (2008).

Problems with positively validating the hypothesis about the migration of dirty industries can be traced in the works of many authors. First, it is often due to the erroneous assumption that environmental costs constitute one of the major cost items to the enterprise. Usually, it is quite the opposite, and their relevance for investment decisions is minor. On top of that, in countries where environmental standards are low, additional difficulties frequently arise, which often means there is a higher risk of potential failure of an investment project. Thus, there is a lack of interest in a given location. These other risk factors include unskilled labour, underdeveloped infrastructure, lack of political or economic stability. In other words, environmental costs are much less relevant to enterprises than other factors decisive for the overall investment climate.

Second, some dirty industries (e.g., the power industry) can operate primarily in close proximity to customers who buy goods and services from them. Hence, moving around in the pursuit of a better (cheaper) location is not of paramount importance. If we add the need to engage in a competitive struggle with

${ }^{4}$ The term "halo effect" derives from psychology and means a tendency to automatically attribute specific traits, positive or negative, to, e.g., concrete persons based on the impression, be it positive or negative, they have made on us. 
local companies (often monopolists supported by local authorities) the opinion that some dirty industries are little motivated to move to other countries seems fully justified.

Third, from an investor's point of view, the clarity and predictability of environmental regulations is crucial. Even if stringent, a fair environmental framework that offers equal treatment to all market participants gives entrepreneurs a sense of stability. Under such circumstances, they see the risk of unpredictable and unfavourable changes in the legislation as minor. The threat of unfavourable regulations increases in poorly developed countries that lack political and economic stability.

In times when corporate the social responsibility concept is increasingly present in different sectors of the economy, migration in the pursuit of low environmental standards may be detrimental to a company's image. Customers whose environmental awareness is continuously growing expect businesses to minimise adverse production effects. In the literature, such an approach is referred to as "green consumerism" (Muldoon 2006; Vanderheiden 2008; Samarasinghe 2012), and it means that customers may, or even should, counteract environmental damage in all sorts of ways, starting with purchasing environmentally friendly goods, through to consciously limiting excessive consumption. Moreover, business managers' values and personal beliefs are also important. Many authors stress their huge impact on how environmental goals are formulated, how eco-solutions are implemented in companies, and how they are integrated with the natural environment through environmentally friendly technologies and products.

In a paper published under the very meaningful title of Pollution Havens and Foreign Direct Investment: Dirty Secret or Popular Myth? Smarzynska and Wei (2001) argue that the problem with providing evidence for pollution havens is twofold. First, they suppose that it is just a myth, a theoretical guess that has not been confirmed by economic reality. Second, they believe it is quite likely to be a "dirty secret" of countries, enterprises, and scientists. They have too little reliable statistical data (often available only for industries, not for individual enterprises), and are unable to prove its existence. The results of their analysis once again failed to prove that pollution havens do exist. The authors themselves admitted that the evidence they had provided was too modest and weak (Smarzynska, Wei 2001, p. 5) to unambiguously answer the question asked in the title. Nevertheless, it should be seen as an incentive to undertake further studies in this area. 


\section{Studies that support the pollution haven hypothesis}

From the above-presented overview of studies, we have learnt that the subject-matter literature is filled with works that reject the hypothesis about dirty industries being displaced to pollution havens. Although these voices dominate in the discussion, the last two decades have witnessed a number of studies that confirm the hypothesis. As an example, we can take the work by Xing and Kolstad (2002) who investigated decisions made by American investors. They considered industries where heavy emitters pay high environmental charges (e.g., the chemical or metalworking industry), as well as industries in which environmental fees represented a minor share of total costs (e.g., electrical, transportation, or food processing). Less stringent foreign environmental regulations were seen as FDI determinants only by investors from the most polluting industries. However, the results of the study should be approached and interpreted with caution because a more relaxed environmental framework was not decisive for the location choice. In other words, it was only evidenced that differences in the stringency of the environmental policy might stimulate capital flows to countries where environmental regulations are less stringent. The authors warn against the negative consequences of such shifts, e.g., an increase in unemployment in capital-exporting countries or environmental damage in the host countries. In addition, the migration of dirty industries does not solve the problem of pollution in developed countries because pollution is usually cross-border by nature (Xing, Kolstad 2002, p.15).

Cole (2004), in turn, found evidence of the existence of pollution havens by analysing the net exports of dirty industries in relation to domestic production and for selected developed and developing countries. He demonstrated that pollution havens are limited regarding geographical scope and that they are usually temporal. His considerations also show that trade liberalisation and the resulting intensified competition in the market may lead developing countries to deliberately relax their environmental standards. Free trade highlights and exacerbates the imperfections of institutional systems. In developed countries, green consumers may exert pressure on the government to impose higher charges on the consumption of green public goods, and more stringent environmental norms are more widely approved than in developing countries (Franzen, Meyer 2010; Bernauer, Koubi 2009).

A positive correlation between FDI inflow indicators and environmental policy can also be seen in the paper by Aminu (2005). An analysis was conducted for 14 poorly developed countries that receive capital from eleven selected OECD countries. The study failed to prove that FDI flows are responsible for greater environmental pollution or bigger energy consumption in the host countries. Only a small connection was revealed between FDI and bigger $\mathrm{CO}_{2}$ emissions. Yet, the 
study arouses some reservations as the statistical data were neither complete nor fully aggregated. A detailed reference to the specificity of pollutants emitted from concrete industries was also missing (Aminu 2005, p. 20).

In a cross-sectoral study conducted for several dozen countries and more than 80 industries, Broner, Bustos and Carvalho (2012) proved that environmental regulations are a statistically relevant location determinant for dirty industries and represent an important source of comparative advantage of many countries. Relaxed environmental standards are equally important production location incentives as human capital (Broner, Bustos, Carvalho 2012, p. 3). Moreover, studies have shown that goods produced by dirty industries in countries with lax environmental regulations have an ever-increasing share in United States imports, confirming the hypothesis about shifting dirty production from highly to poorly developed countries.

When examining the relationship between the intensity of FDI inflows and the stringency of environmental regulations, we may additionally consider the nature of investment (horizontal or vertical). The key reason behind an investment determines the ultimate choice of the host country that has a specific environmental regulatory framework.

Rezza (2013) attempted to discover whether, depending on the motivation, investors deliberately choose or reject countries of low environmental standards. His study was conducted for Norwegian enterprises engaged in FDI over the period 1999-2005, and the cross-sectional data referred to transactions concluded between parent companies and their foreign affiliates. He demonstrated that parent companies invest less in their foreign affiliates regarding vertical investment in countries with stringent environmental regulations. Additionally, in such cases, exports from the affiliates to the parent company decrease. On the other hand, for horizontal FDI, the stringency of environmental standards in the host country becomes irrelevant to investors.

As Rezza observed, such conclusions concur, to a certain extent, with the findings of Markusen and Maskus (2001), who used examples of enterprises from the United States to demonstrate that FDI undertaken for reasons other than the wish to win new or expand existing markets are more sensitive to investment cost. Thus, additional costs paid to comply with environmental norms are of huge importance to investors. Aware of such expenses, a multinational corporation can always choose another location, which is why, for vertical investment, it is more likely to choose a country with a less stringent environmental framework.

On the other hand, Ben Kheder (2010) tries to answer the question of whether FDI increases pollutant emissions in the host country. As an example, the author takes French FDI targeting regions at diverse levels of economic development in the period 1999-2003. The results suggested that in countries that host French FDI, there is a correlation between investment and $\mathrm{CO}_{2}$ emissions, as well as 
water contamination. This confirms the carbon leakage effect, i.e., the relocation of energy-consuming and high-carbon production from countries that wish to reduce greenhouse gas emissions to countries that do not plan such measures.

The problem of carbon leakage has been observed by researchers for two decades. Its scale is substantial, often estimated at more than ten percent of primary reduction, although some estimates suggest carbon leakage of several dozen percent (Aichele, Felbermayr 2010). Industries such as organic chemistry, steel and iron, glass, cement, or paper production are the most exposed to the phenomenon, although a complete list of industries exposed to the risk of carbon leakage to third countries includes several dozen items (European Commission 2009).

Ben Kheder's study also demonstrated that French FDI made by "cleaner" industries reduce pollutant emissions in the host countries. That is the effect of cleaner (more environmentally friendly) technologies used not only by investors but also by their business partners. It is also the outcome of using other (better) management and work organisation systems, as well as the dissemination of know-how.

Similar conclusions were formulated by Dean and Lovely (2008), who examined the polluting aspects of international trade over the period 1995-2004 and the impact of FDI on environmental contamination in China. Their study revealed that intensified export operations of foreign affiliates lead to the reduction of harmful emissions due to the use of environmentally friendly technologies. At the same time, the analysis showed a bigger polluting impact of Chinese enterprises that manufacture goods for export.

Gamper-Rabindran and Jha (2004), using the case of India, demonstrated that when the economy opened after 1991, exports of dirty goods increased, together with the inflow of FDI from dirty industries. They believe that it confirms the hypothesis about the negative impact of trade liberalisation on the environment in poorly developed countries and another hypothesis about the migration of enterprises seeking to launch their operations in a less stringent environmental regulatory framework. Studies have demonstrated that the openness of the economy leads to enhanced exports in industries which heavily contaminate water and air. The above conclusions, however, arouse some reservations mainly concerning the numerous simplifications in the model. ${ }^{5}$

Similar studies have been carried out in many other regions of the world. Waldkirch and Gopinath (2004) revealed a connection between increased contamination and FDI inflow to Mexico. The strongest relationship was found for $\mathrm{SO}_{2}$ emissions, whose sources are usually anthropogenic. The results of their study showed a correlation between FDI and pollutant emissions in only a few industries. Nevertheless, these industries attracted ca. $40 \%$ of FDI over the period covered by the study.

\footnotetext{
${ }^{5}$ Other studies do not confirm these conclusions (Dietzenbacher, Mukhopadhyaya 2007; Mukhopadhyay, Chakraborty 2005; Jeny, Sahu, Rath 2005; Chakraborty 2010).
} 
Another study, this time focused on Thailand, also confirmed the negative impact of FDI and enhanced exports of foreign affiliates of multinational enterprises on environmental pollution (Mukhopadhyay 2006). The author observes that the results of the analysis can be extended to other countries, such as Malaysia, the Philippines, or China. All these countries have followed a similar development path based on exports and attracting foreign investors. Even though their environmental regulations are more stringent compared to Thailand, they are much more relaxed than in OECD countries. For that reason, the likelihood that the above-mentioned countries have or will become pollution havens in the future is remarkably high.

When examining the pollution haven hypothesis, it is also worth looking at the concentration of companies from the industry in question and their competitive position. Concentration contributes to improved efficiency, competitiveness and the overall better performance of enterprises. It also facilitates "shifting" environmental costs over to the consumers. If there is no concentration, meeting environmental standards becomes more expensive for enterprises. Under such circumstances, it is likely that a company would be willing to increase dirty imports from countries where environmental standards are more relaxed.

The problem has been addressed by, e.g., Ritz (2009) and Batrakova (2012). Ritz demonstrates that the threat of $\mathrm{CO}_{2}$ leakage is much greater in markets where there is little competition. On the other hand, Batrakova refers to the degree of industry concentration and its impact on the extensive and intensive margin of dirty imports after the European Union Emissions Trading System was put in place. Her studies confirm that Irish enterprises that operate in markets where there was no industry concentration increased dirty imports from non-OECD countries. That was especially visible after 2005 when the costs of production of dirty goods in the country increased. It means that environmental costs in the home country, similarly to little industry concentration, intensified the carbon leakage phenomenon and increased polluting imports.

Interesting conclusions can be found in the work by Cole, Elliott and Fredriksson (2006). Their research showed that FDI impacts the stringency of environmental standards, although only in countries where corruption levels are high. It means that the bigger (smaller) the corruption, the more relaxed (stringent) the environmental regulations.

\section{Conclusion}

Liberalising capital flows and abolishing trade barriers in the global economy help multinational corporations to move more easily to optimise conditions for their operations. Many contemporary researchers draw attention to the fact that environmental regulations may become one of the determinants that attract foreign 
companies to the region, thus giving it a comparative advantage over competitors. Discussions that have taken place for many years seem to take it for granted that dirty industries in developed countries are looking for new locations where environmental standards are lower, and where meeting them is less costly to enterprises. There is also a general belief that little developed countries turn into pollution havens and often pursue the "race to the bottom" strategy wishing to attract FDI.

Thus, giving a definitive answer to the question of whether dirty industries are looking for pollution havens is difficult. The overview of the subject-matter literature does not provide us with unambiguous conclusions. It is clear, however, that while until the late 1990s, the existence of pollution havens was mostly questioned; meanwhile, in the last two decades, there have been many studies which confirm that pollution havens exist. Access to increasingly more detailed databases and more accurate pollution emission measurements have helped the authors in demonstrating that developed countries practice the "environmental exploitation" of developing countries. It happens due to dirty investment and dirty production (mainly for exports) feasible as a result of, inter alia, the liberalisation of international trade.

We should not forget the carbon leakage problem, i.e. $\mathrm{CO}_{2}$ leakage taking place as a result of relocating energy-consuming and high-emission production from countries which reduce greenhouse gas emissions to countries which do not plan to adopt such measures. By observing these trends and the carbon footprint of products traded in the global market, researchers are ready to admit that $\mathrm{CO}_{2}$ emissions are "leaking" from highly to less developed economies. Despite efforts made by many countries to reduce emissions, global $\mathrm{CO}_{2}$ emissions are increasing at an unprecedented rate. It is hard to challenge the above observations, especially when the subject matter literature (mainly from the last decade) confirms that carbon leakage exists.

As already mentioned, the results of many studies that focused on the migration of dirty industries are neither unambiguous nor unquestionable. But that surely means that the issue will continue to stir interest among researchers for many years to come.

\section{References}

Aichele R., Felbermayr G. (2010), Kyoto and the carbon content of trade, "FZI D Discussion Paper", 10, pp. 1-63.

Aminu A.M. (2005), Foreign Direct Investment and the Environment: Pollution Haven Hypothesis Revisited, Paper prepared for the Eight Annual Conference on Global Economic Analysis, Lübeck, Germany, June 9-11, https://www. gtap.agecon.purdue.edu/resources/download/2131.pdf (accessed: 1.12.2019). 
Asghari M. (2013), Does FDI Promote MENA Region's Environment Quality? Pollution Halo or Pollution Haven Hypothesis, "International Journal of Scientific Research in Environmental Sciences", 1 (6), pp. 92-100.

Bartik T.J. (1988), The Effects of Environmental Regulation on Business Location in the United States, "Growth and Change", 19 (3), pp. 22-44.

Batrakova S. (2012), Does industry concentration matter for pollution haven effects?, Centre for Climate Change Economics and Policy Working Paper No. 106, Grantham Research Institute on Climate Change and the Environment, Working Paper No. 90, September, pp. 1-29.

Ben Kheder S. (2010), French FDI and Pollution Emissions: An Empirical Investigation, November, pp. 1-44. http://www.cerdi.org (accessed: 1.12.2019).

Bernauer T., Koubi V. (2009), Effects of Political Institutions on Air Quality, "Ecological Economics", 68 (5), pp. 1355-1365.

Birdsall N., Wheeler D. (1993), Trade policy and industrial pollution in Latin America: where are the pollution havens?, "Journal of Environment and Development", 2 (1), pp. 137-147.

Broner F., Bustos P., Carvalho V.M. (2012), Sources of comparative advantage in polluting industries, "NBER Working Paper Series", No. 18337, pp. 1-51.

Chakraborty D. (2010), Does Pollution Haven Hypothesis Holds Good for India? Evidence from Cross-State FDI Inflow Patterns, pp. 1-30, https://www.apeaweb.org/confer/hk10/.../chakraborty_d.pdf (accessed: 1.12.2019).

Chodyński A. (2011), Odpowiedzialność ekologiczna w proaktywnym rozwoju przedsiębiorstw, Krakowska Akademia im. Andrzeja Frycza Modrzewskiego, Kraków.

Cole M.A. (2004), Trade, the pollution haven hypothesis and the environmental Kuznets curve: Examining the linkages, "Ecological Economics", 48 (1), pp. $71-81$.

Cole M.A., Elliott R.J.R., Fredriksson P.G. (2006), Endogenous pollution havens: Does FDI influence environmental regulations?, "Scandinavian Journal of Economics", 108 (1), pp. 157-178.

Czaja S. (2004), Wpływ wspótczesnego neokolonializmu ekologicznego na globalizacje problemów środowiskowych, [in:] Budnikowski A., Cygler M. (eds.), Ochrona środowiska a procesy integracji i globalizacji, Oficyna Wydawnicza SGH, Warszawa.

Dean J.M., Lovely M.E., Wang H. (2009), Are foreign investors attracted to weak environmental regulations? Evaluating the evidence from China, "Journal of Development Economics", 90, pp. 1-13.

Dietzenbacher E., Mukhopadhyay K. (2007), An Empirical Examination of the Pollution Haven Hypothesis for India: Towards a Green Leontief Paradox?, "Environmental \& Resource Economics", 36 (4), pp. 427-449. 
Eskeland G., Harrison A. (2002), Moving to Greener Pastures? Multinationals and the Pollution Haven Hypothesis, "NBER Working Paper", No. 8888, pp. 1-38.

Franzen A., Meyer R. (2010), Environmental Attitudes in Cross-National Perspective: A Multilevel Analysis of the ISSP 1993 and 2000, "European Sociological Review", 26 (2), pp. 219-234.

Friedman J., Gerlowski D.A., Silberman J. (1992), What Attracts Foreign Multinational Corporations? Evidence from Branch Plant Location in The United States, "Journal of Regional Science", 32 (4), pp. 403-418.

Gallagher K., Zarsky L. (2007), The Enclave Economy: Foreign Investment and Sustainable Development in Mexico's Silicon Valley, MIT Press.

Gamper-Rabindran S., Jha S. (2004), Environmental Impact of India's Trade Liberalization, June, pp. 1-40, http://dx.doi.org/10.2139/ssrn.574161. (accessed: 15.12.2019).

Goodstein E.B. (1994), Jobs and the Environment. The Myth of a National TradeOff, Economic Policy Institute, Washington, D.C.

Jena P.R., Sahu N.C., Rath B. (2005), Does Trade Liberalisation Create Pollution Haven? An Indian Experience, paper presented at the "International Conference on Environment and Development: Developing Countries Perspective", April 7-8, 2005, International Trade and Development Division, Jawaharlal Nehru University, New Delhi.

Jiang L., Lin Ch., Lin P. (2014), The Determinants of Pollution Levels: Firm-Level Evidence from Chinese Manufacturing, "Journal of Comparative Economics", 42 (1), pp. 118-142.

Kirkpatrick C., Shimamoto K. (2008), The effect of environmental regulation on the locational choice of Japanese foreign direct investment, "Applied Economics", 40 (11), pp. 1399-1409.

Komisja Europejska (2009), Commission Decision of 24 December 2009 determining, pursuant to Directive 2003/87/EC of the European Parliament and of the Council, a list of sectors and subsectors which are deemed to be exposed to a significant risk of carbon leakage (notified under document $\mathrm{C}(2009)$ 10251).

Levinson A. (1996), Environmental regulations and manufacturers' location choices: Evidence from the Census of Manufactures, "Journal of Public Economics", 61 (1), pp. 5-29.

Liang F.H. (2008), Does Foreign Direct Investment Harm the Host Country's Environment? Evidence from China, SSRN Working Paper, http://www.papers. ssrn.com/sol3/papers.cfm?abstract id=1479864 (accessed: 15.12.2019).

Low P., Yeats A. (1992), Do "Dirty” Industry Migrate?, [in:] Low P. (ed.), International Trade and the Environment, "World Bank Discussion Papers", No. 159, World Bank, Washington D.C., pp. 89-103. 
Markusen J.R., Maskus K.E. (2001), Multinational firms: reconciling theory and evidence, [in:] Blomstrom M., Goldberg L. (eds.), Topics in Empirical International Economics: A Festschrift in Honor of Robert Lipsey, University of Chicago Press for National Bureau of Economic Research, Chicago, IL.

Mukhopadhyay K. (2006), Impact on the Environment of Thailand's Trade with OECD Countries, "Asia-Pacific Trade and Investment Review”, 2, pp. 25-46.

Mukhopadhyay K., Chakraborty D. (2005), Is liberalization of trade good for the environment? Evidence from India, "Asia-Pacific Development Journal", 12 (1), pp. 109-136.

Muldoon A. (2006), Where the Green Is: Examining the Paradox of Environmentally Conscious Consumption, "Electronic Green Journal”, 23, April, pp. 1-15.

Pietrewicz J.W. (2011), Ochrona środowiska w warunkach procesów globalizacji, Wydawnictwo SGH, Warszawa.

Rezza A.A. (2013), FDI and pollution havens: Evidence from the Norwegian manufacturing sector, "Ecological Economics", 90, pp. 140-149.

Ritz R.A. (2009), Carbon leakage under incomplete environmental regulation: An industry-level approach, "Economics Series Working Papers", No. 461, University of Oxford, Department of Economics, pp. 1-33.

Samarasinghe R. (2012), Green consumerism. Individual's ethics and politics as predictors of pro-environmental behavior, "Delhi Business Review", 13 (1), January-June, pp. 41-48.

Smarzynska B., Wei S-J. (2001), Pollution Havens and Foreign Direct Investment: Dirty Secret or Popular Myth?, "NBER Working Paper", No. 8465, September.

Vanderheiden S. (2008), Green Consumerism: Saving the World at the Cash Register?, Conference Papers - Western Political Science Association, Annual Meeting, pp. 1-19.

Waldkirch A., Gopinath M. (2004), Pollution Haven or Hythe? New Evidence from Mexico, International Trade 0412005, Economics Working Paper Archive at WUSTL, pp. 1-34.

Walter I. (1973), The Pollution Content of American Trade, "Western Economic Journal", 11 (1), pp. 61-70.

Wang H., Jin Y. (2002), Industrial Ownership and Environmental Performance: Evidence from China, "World Bank Policy Research Working Paper", No. 2936, pp. 1-28.

Wheeler D. (2001), Racing to the Bottom? Foreign Investment and Air Pollution in Developing Countries, "Journal of Environment and Development", 10 (3), pp. 225-245.

Xing Y., Kolstad Ch.D. (2002), Do Lax Environmental Regulations Attract Foreign Investment?, "Environmental and Resource Economics", 21 (1), pp. 1-22.

Zarsky L. (1999), Havens, Halos and Spaghetti: Untangling the Relationship Between FDI and the Environment, [in:] Foreign Direct Investment and the Environment, Paris, OECD, pp. 47-73. 


\section{Summary}

The paper aims to present an overview of theoretical and empirical studies dedicated to "dirty" industries that migrate to pollution havens. It consists of three parts. The first one discusses the major determinants that trigger the migration of dirty industries. Next, attention is paid to the results of studies which reject the hypothesis about the existence of pollution havens. Part three addresses the ideas and concepts that validate this hypothesis and confirm that dirty industries move to countries with a more relaxed environmental regulatory regime. The paper finishes with a summary section presenting the main conclusions from the analysis.

Keywords: environment, environment pollution, pollution havens, "race to the bottom", foreign direct investment

\section{Streszczenie}

Czy „brudne” przemysły poszukują rajów dla zanieczyszczeń? - przegląd wybranych badań

Celem artykułu jest dokonanie przeglądu badań teoretycznych i empirycznych odnoszących się do migracji „brudnych” gałęzi przemysłu do rajów dla zanieczyszczeń. Artykuł składa się z trzech części. W pierwszej przedstawiono główne determinanty przemieszczania się „,brudnych” przemysłów. Następnie omówiono wyniki badań, które odrzucają hipotezę o istnieniu rajów dla zanieczyszczeń. W trzeciej części odniesiono się do tych koncepcji, które weryfikują jej prawdziwość i potwierdzają, że „brudne” przemysły przemieszczają się do krajów, w których przepisy prawne dotyczące ochrony środowiska nie są restrykcyjne. Artykuł kończy się podsumowaniem, w którym przedstawiono najważniejsze wnioski z przeprowadzonej analizy.

Słowa kluczowe: środowisko przyrodnicze, zanieczyszczenie środowiska, raje dla zanieczyszczeń, „wyścig do dna”, zagraniczne inwestycje bezpośrednie

JEL: F18, F64. 